\title{
OPTIMALISASI MUTU LULUSAN DENGAN PEMBEKALAN KETERAMPILAN BERHITUNG MODEL MARS (MATEMATIKA DAN ARITMATIKA SEDERHANA)
}

\author{
Wahyudi, Intan Sari Rufiana, Dwi Avita Nurhidayah \\ Universitas Muhammadiyah Ponorogo, Ponorogo, Indonesia \\ wahyudibooleng@yahoo.co.id
}

\begin{abstract}
Abstrak: Tujuan kegiatan pengabdian kepada masyarakat ini (PKM) adalah memberikan keterampilan terkait dengan kemampuan aritmetika sederhana pada mahasiswa Program Studi Pendidikan Matematika Universitas Muhammadiyah Ponorogo khususnya pada Operasi Aljabar (Penjumlahan dan Pengurangan). Keterampilan ini termasuk di luar kompetensi utama yang mendukung keilmuan. Dengan adanya kegiatan ini diharapkan dalam implementasinya, mahasiswa mampu bersaing dengan lulusan dari Perguruan Tinggi lain. Kegiatan ini dilaksanakan untuk (1) mempersiapkan dan membekali para calon pendidik khususnya mahasiswa program studi matematika Fakultas Keguruan dan Ilmu Pendidikan Universitas Muhammadiyah Ponorogo Semester VI dan Semester VIII dalam hal berhitung cepat, (2) memberikan motivasi pada mahasiswa untuk memiliki keterampilan lain yang mendukung keilmuan. Kegiatan ini dilaksanakan melalui kegiatan pelatihan keterampilan berhitung dengan menggunakan jarimatika. Dapat disimpulkan bahwa kegiatan pelatihan ini dapat membangkitkan motivasi dan membekali mahasiswa dengan keterampilan lain yang mendukung keilmuannya. Dari 30 mahasiswa yang mengikuti kegiatan PKM, sebanyak 50\% berpendapat bahwa model berhitung ini sangat mudah diterapkan, 30\% menyatakan mudah diterapkan, dan sisanya menyatakan cukup mudah diterapkan. Selain itu, 53\% dari 30 peserta sangat paham terhadap konsep berhitung menggunakan jarimatika, $27 \%$ dari 30 peserta menyatakan paham, $17 \%$ menyatakan cukup paham dan $3 \%$ menyatakan sulit.
\end{abstract}

Kata kunci: optimalisasi keterampilan, berhitung matematika, jarimatika

\begin{abstract}
The purpose of this community service program is to provide students with simple arithmetic skills in the Mathematics Education Study Program at Universitas Muhammadiyah Ponorogo, especially in Algebra Operations (addition and subtraction) which include as the supporting competencies. This program is expected to prepare students for competing with graduates from other tertiary institutions. It was carried out to (1) prepare and equip prospective mathematics teachers in terms of fast counting, (2) provide motivation for students to have other skills that support their main competences. The program was in the form of numeracy skills training using Jarimatika. Of the 30 students who took part; $50 \%$ of the students agreed that the numeracy model is very easy to implement, 30\% said it was easy to apply, and the rest stated it was quite easy to apply. In addition, 53\% of the 30 participants understood the concept of arithmetic using Jarimatika, 27\% expressed understanding, 17\% stated that they understood well, and 3\% stated that it was difficult. The program can arouse motivation and equip students with additional skills that can support their knowledge.
\end{abstract}

Keywords: optimization of skills; math counting; jarimatika

\section{Pendahuluan}

Mata pelajaran matematika sampai saat ini menjadi hal menakutkan bagi beberapa siswa. Hal ini juga diungkapkan oleh Tambychik dan Subahan (2010) yang mengatakan bahwa kesulitan dan ketidaksukaan masih sering dialami oleh siswa. Kesulitan ini seperti, operasi penjumlahan, pengurangan, pembagian dan perkalian. Apalagi jika siswa bertemu dengan berbagai bilangan yang masing-masing operasikan dengan keempat operasi. Tidak hanya itu, siswa juga mengalami kesulitan saat menghitung bilangan-bilangan yang tidak seperti biasanya, 
seperti bilangan puluhan, ratusan, dan sebagainya. Terkadang siswa mengalami kesulitan dalam konsep perhitungan itu sendiri. Seperti pendapat Mulwa (2015) yang menyatakan bahwa beberapa siswa mengalami kesulitan dalam konsep matematika. Dengan demikian, diharapkan dengan adanya kegiatan pelatihan ini dapat mengurangi kesulitan berhitung dan konsep perhitungan bagi mahasiswa.

Untuk menciptakan pembelajaran yang lebih bermakna dan mempermudah siswa dalam menghitung suatu bilangan, guru perlu mengembangkan suatu metode berhitung sehingga siswa tidak merasa kesulitan. Darsono (2000) menjelaskan bahwa seorang guru mempunyai peran untuk membantu siswa dalam mencapai tujuan yang diharapkan dengan menggunakan strategi dan metode yang dapat meningkatkan minat belajar siswa. Dengan menggunakan aktivitas menghitung dengan kreatifitas yang bagus, maka siswa mampu menggunakan otak kiri dan kanannya. Hal ini sesuai dengan pendapat Khumaidah (2007) dan juga Syifa \& Simatupang (2015) yang menyatakan bahwa berhitung dengan jarimatika (sempoa) dapat mengembangkan otak kiri dan kanan siswa.

Metode yang digunakan adalah metode menghitung dengan jari-jari mereka yang disebut jarimatika. Dengan adanya media jarimatika, siswa mampu merangkai kemampuan mereka yang sebelumnya belum muncul. Hal ini dikuatkan oleh pendapat Anthony dan Walshaw (2009) yang menyatakan bahwa siswa didukung oleh guru yang efektif dengan berbagai pengembangan matematika atau media pembelajaran. Wulandari (2008) menjelaskan bahwa salah satu cara untuk melatih kemampuan berhitung anak-anak adalah dengan menggunakan metode Jarimatika. Jarimatika adalah cara berhitung yang terdiri dari operasi kali, bagi, tambah, kurang dengan menggunakan jari-jari tangan.

Menurut Astuti (2013) jarimatika merupakan suatu cara yang mempermudah perhitungan matematika dan membuat siswa senang berhitung dengan menggunakan jari-jari mereka sendiri. Hal ini juga disebutkan oleh Wulandari (2013) bahwa jarimatika merupakan sebuah cara sederhana dan menyenangkan. Jarimatika mengajarkan berhitung dasar kepada anak-anak menurut kaidah: dimulai dengan memahamkan secara benar terlebih dahulu tentang konsep bilangan, lambang bilangan, dan operasi hitung dasar, kedua barulah kemudian mengajarkan cara berhitung dengan jari-jari tangan, dan akhirnya prosenya diawali, dilakukan dan diakhiri dengan gembira. Pernyataan Wulandari (2013) sejalan dengan pendapat Sitio (2017) yaitu metode jarimatika merupakan bentuk pembelajaran yang sangat menarik dan memudahkan siswa untuk dapat menyelesaikan tugas-tugas yang diberikan oleh guru. Keadaan seperti ini memungkinkan dapat meningkatkan hasil belajar siswa, karena dengan ketertarikan siswa terhadap metode ini maka siswa lebih berminat untuk mengikuti pembelajaran matematika.

Menurut Abdullah (2012) jarimatika ini sangat membantu siswa dalam menghitung dengan mudah saat mereka menyelesaikan suatu soal matematika yang kaitannya dengan artimatika. Dengan demikian, siswa dapat meningkatkan kreatifitas berhitung dengan menggunakan jari-jari mereka. Untuk meningkatkan kemampuan siswa dalam berhitung dengan jarimatika, diadakan kegiatan yang bertema model berhitung MARS (Matematika dan Aritmetika sederhana). 
Model berhitung MARS ini merupakan model perhitungan jarimatika dengan menekankan konsep terlebih dahulu sebelum cara cepatnya. Diharapkan dengan penguasaan konsep terlebih dahulu, pemahaman siswa dapat dioptimalkan. Sehingga siswa berhitung tidak cepat lupa karena telah memahami konsep terlebih dahulu. Dibandingkan dengan metode lain, metode jarimatika ini menuntun siswa untuk menguasai konsep terlbih dahulu sehingga anak-anak menguasai ilmunya dengan matang. Selain itu anak-anak juga akan merasa lebih senang (Abdullah, 2012).

Kegiatan pengabdian kepada masyarakat (PKM) ini bertujuan untuk mempersiapkan dan membekali para calon pendidik khususnya mahasiswa program studi matematika Fakultas Keguruan dan Ilmu Pendidikan Universitas Muhammadiyah Ponorogo Semester VI dan Semester VIII. Dengan kegiatan ini, diharapkan mahasiswa mempunyai skill yang bagus terkait dengan mengitung aritmetika sederhana, sehingga dalam mengajar pada nantinya, mahasiswa mampu bersaing dalam dunia kerja (khususnya mendidik). Hal ini di dukung oleh pendapat Mulwa (2015) yang menyatakan bahwa kemampuan guru pendidik juga harus diperhatikan agar pembelajaran berjalan dengan baik.

Kegiatan ini sangat penting dilaksanakan, karena kegiatan ini dapat mengasah otak kanan dan kiri siswa dalam melakukan berhitung. Hal ini sesuai dengan pendapat Mulyono, Hadiyah, dan Suparno (2012) yang menyatakan bahwa teknik berhitung model Mars dengan menggunakan Jarimatika mampu menyeimbangkan kemampuan kerja otak kanan dan otak kiri serta teknik ini lebih mengutamakan pemahaman konsep lebih dahulu kemudian menggunakan jari-jari tangan. Sebelum mahasiswa memberikan kontribusinya ke masyarakat khususnya mengajar ke sekolah, kegiatan ini diberikan untuk membekali mahasiswa dalam menerapkan dan mengamalkan ilmunya. Dengan demikian, mahasiswa mampu bersaing dalam dunia kerja dengan kemampuan berhitung model MARS dan siswa-siswa yang akan di ajar nantinya akan merasa senang dan suka dengan matematika. Akhirnya pembelajaran yang dilakukan oleh siswanya akan menjadi pembelajaran yang bermakna.

Dalam dunia kerja, mahasiswa mengalami kesulitan untuk memperoleh kesempatan untuk mencari tempat mengabdi, hal ini disebabkan oleh kurangnya kemampuan keterampilan yang di miliki oleh mahasiswa. Dari borang prodi Pendidikan Matematika 2016 diketahui bahwa hasil tracer menunjukkan bahwa tanggapan dari pihak pengguna dalam mengembangan diri lulusan Prodi Pendidikan Matematika hanya $21,28 \%$ dalam kategori baik, selebihkan dalam kategori kurang. Untuk itu dirokemendasikan oleh program Studi untuk terus mendorong mahasiswa mengikuti kegiatan dalam meningkatkan kemampuan (skill). Dosen juga diarahkan untuk selalu menyelenggarakan kegiatan pelatihan yang memuat peningkatan kompetensi mahasiswa.

Hasil yang diharapkan berikutnya dari kegiatan pengabdian ini adalah (1) terselenggaranya pelatihan model mengitung MARS (Matematika dan Aritmetika sederhana) bagi mahasiswa program studi matematika Fakultas Keguruan dan Ilmu Pendidikan Universitas Muhammadiyah Ponorogo Semester VI dan Semester VIII, (2) Hasilnya adalah mahasiswa program studi matematika Fakultas Keguruan dan Ilmu Pendidikan Universitas Muhammadiyah Ponorogo Semester VI dan Semester VIII memiliki kemampuan dalam berhitung dengan jarimatika yang dikemas dalam pengabdian mengenai Model Berhitung MARS (Matematika dan 
Aritmatika Sederhana) untuk Menyiapkan Mahasiswa Prodi Pendidikan Matematika Universitas Muhammadiyah Ponorogo yang siap kerja.

\section{Metode}

Berdasarkan permasalahan yang diuraikan pada bagian pendahuluan di atas, kegiatan PKM ini merupakan kegiatan pelatihan. Pelaksanaan kegiatan ini diselenggarakan di Program Studi Pendidikan Matematika. Jumlah peserta dalam kegiatan PKM ini sebanyak 30 mahasiswa yang terdiri dari mahasiswa semester VI dan VIII Program Studi Pendidikan Matematika Universitas Muhammadiyah Ponorogo. Kegiatan ini dilaksanakan pada tanggal 21 Desember 2018 di ruang laboratorium micro teaching.

Pertimbangan penetapan mahasiswa sebagai sasaran dari kegiatan pengabdian masyarakat ini karena penyelenggara beranggapan bahwa yang paling membutuhkan keterampilan ini adalah mahasiswa. Hal ini dilakukan dalam rangka untuk optimalisasi mutu lulusan program studi pendidikan matematika. Disamping dituntut untuk memiliki keilmuan yang mendalam, lulusan program studi pendidikan matematika juga diharapkan memiliki keterampilan lain yang mendukung keilmuannya.

Metode yang digunakan dalam pelaksanaan kegiaran PKM ini adalah metode pelatihan berhitung model MARS. Menurut Wahyuni (2016) metode pelatihan (drill) sangat cocok/tepat untuk memperoleh kecakapan mental (seperti dalam hal penjumlahan dan pengurangan). Hal ini diperkuat oleh pendapat Primayanti, Suwu, dan Appulembang (2018) yang menyatakan bahwa dengan adanya metode drill dapat meningkatkan keterampilan siswa melalui pemberian latihan secara berulang untuk menanamkan kebiasaan dan memperoleh kecakapan.

Kegiatan dilakukan dengan pemberian materi yang disampaikan dengan ceramah oleh Puguh Gendrowiyono, M.Si (P.Si) selaku pemateri. Mahasiswa melakukan praktik langsung dengan menggunakan jari tangan kiri dan kanan dengan bantuan lembar kerja yang telah disediakan. Diakhir kegiatan dilakukan post test dalam rangka mengukur ketercapaian pemahaman mahasiswa terhadap materi yang telah disampaikan.

Beberapa langkah diperlukan dalam penyelenggaraan kegiatan ini. Langkah itu meliputi: (1) persiapan kegiatan yang dilakukan oleh Tim Penyelenggara PKM untuk mengidentifikasi permasalahan mahasiswa; (2) merencanakan kegiatan dengan memperhatikan pertimbangan waktu, materi dan teknis kegiatan PKM; (3) pelaksanaan kegiatan pelatihan dalam rangka untuk meningkatkan keterampilan mahasiswa dan memberikan motivasi; (4) mengevaluasi kegiatan PKM yang dilakukan oleh peserta PKM dan Penyelenggara PKM.

\section{Hasil dan Pembahasan}

Pelaksanaan kegiatan pengabdian dimulai dengan persiapan panitia dengan menyiapkan berbagai fasilitas yang dibutuhkan seperti halnya mengidentifikasi permasalahan mitra, merencanakan kegiatan yang terkait dengan waktu, materi dan teknis kegiatan, serta praktek secara kolektif oleh masing-masing peserta dengan bimbingan pemateri. Berikut adalah aktivitas persiapan panitia dan kehadiran peserta pengabdian. Tepat jam 13.00 WIB kegiatan 
pengabdian masyarakat 2018 resmi dilaksanakan dan dibuka oleh ketua pelaksana. Kegiatan pengabdian masyarakat 2018 dibuka dengan sambutan ketua pelaksana yaitu Wahyudi, S.Si, M.Pd. Kegiatan pengabdian dibuka setelah para peserta dan pemateri sudah hadir di tempat pelaksanaan. Kemudian, ketua pelaksana memberikan pengantar materi kegiatan pengabdian masyarakat 2018 kepada peserta kegiatan pengabdian. Gambar 1 menunjukkan ketua pelaksana kegiatan pengabdian masyarakat 2018 sedang membuka kegiatan dan memberikan pengantar materi kegiatan PKM.

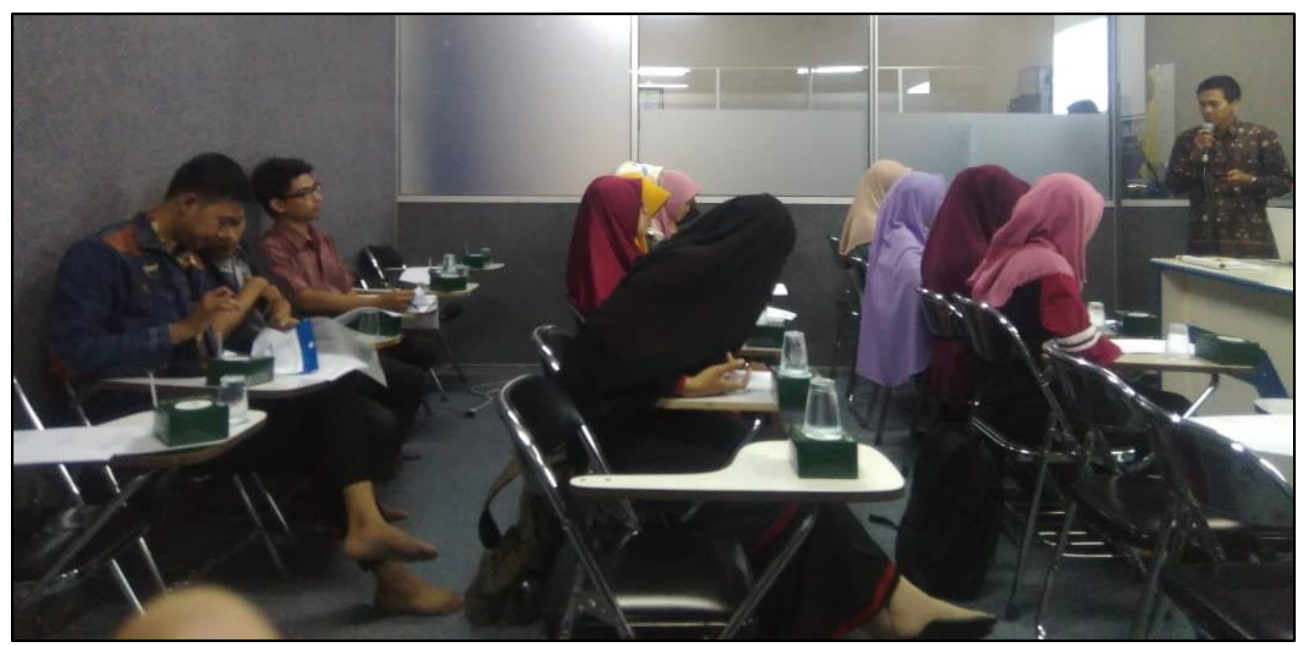

Gambar 1. Pengantar Materi Kegiatan Pengabdian Masyarakat 2018

Pemateri lainnya pada kegiatan pengabdian masyarakat 2018 adalah Ir. Puguh Gendrowiyono, M.Si (P.Si). Beliau adalah direktur Bima Kusuma Learning Center (BLC) Madiun. Dengan demikian, ketua pelaksana pengabdian masyarakat 2018 Universitas Muhammadiyah Ponorogo berkolaborasi dan bekerjasama dengan lembaga BLC untuk memberikan materi pada kegiatan pengabdian masyarakat 2018. Adanya kolaborasi ini agar memberikan luaran yang baik, karena menggabungkan dua informasi dari pihak luar dan informasi dari program sendiri bagaimana kondisi mahasiswa selama ini. Gambar 2 menunjukkan pemateri yang lain saat memberikan materi kepada peserta kegiatan pengabdian masyarakat 2018.

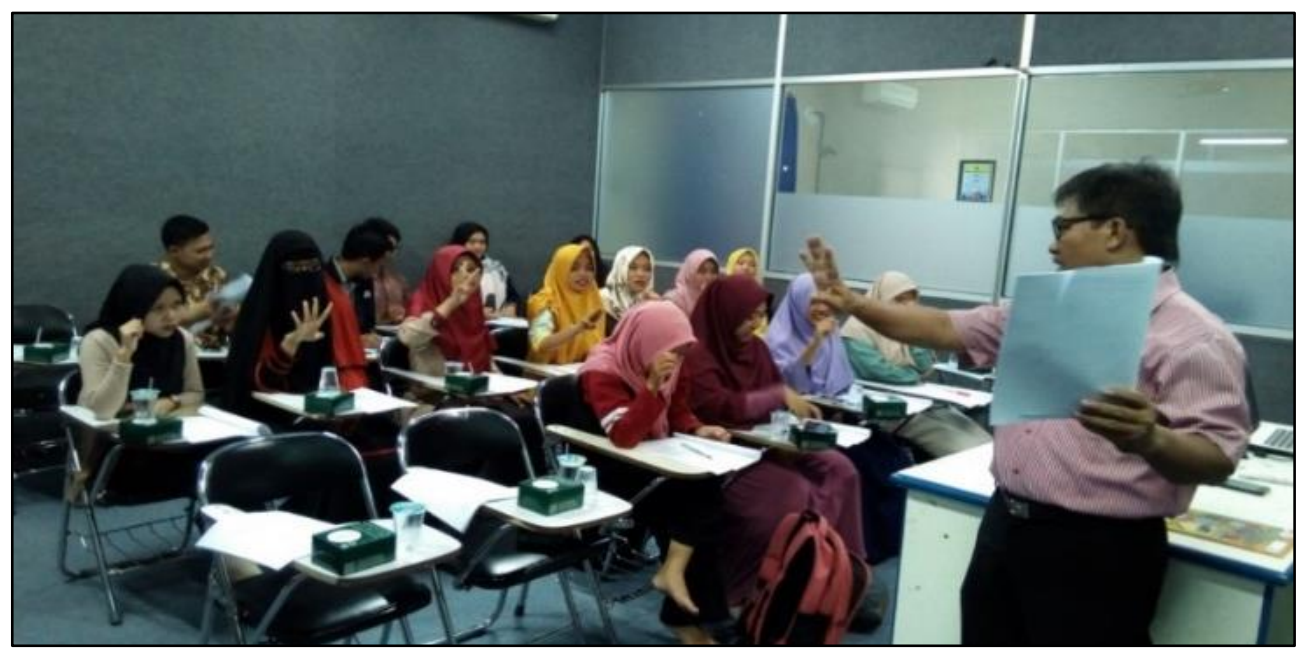

Gambar 2. Pemateri II dalam Kegiatan Pengabdian Masyarakat 2018 
Antusiasme peserta kegiatan pengabdian msyarakat ini sangat tinggi. Gambar 3 menunjukkan bahwa para peserta sangat antusias dan mencoba untuk mempraktikkan apa yang telah diberikan oleh pemateri. Setelah diberikan pengantar tentang berhitung, peserta diberikan waktu untuk mencoba sendiri dan dicocokkan bersama. Interaksi pemateri dan peserta kegiatan dalam pembahasan contoh soal berhitung berlangsung dengan baik.

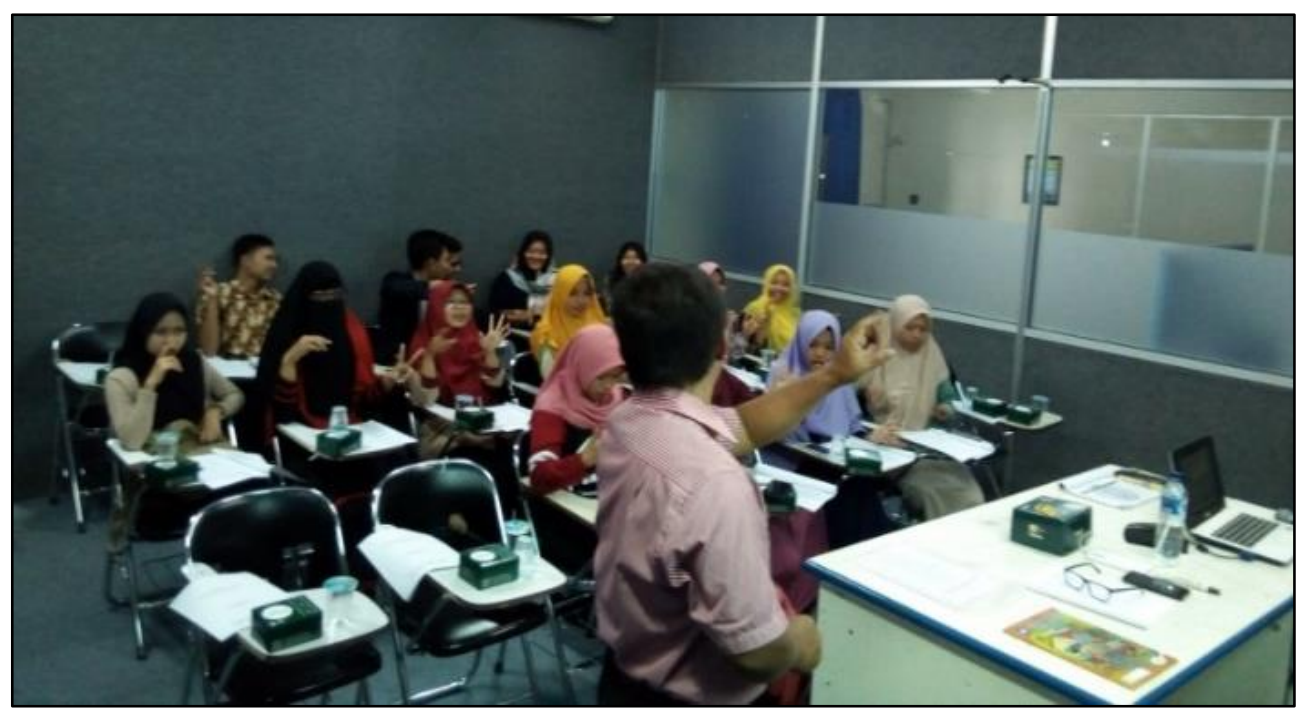

Gambar 3. Interaksi Pemateri dan Peserta Kegiatan Pengabdian

Kegiatan pengabdian masyarakat 2018 ini dilaksanakan selama 5 jam, dimulai dari pembukaan pelatihan, pemberian wawasan dan motivasi adanya kegiatan pelatihan, sampai evaluasi kolektif praktek yang diperhatikan langsung oleh pemateri. Adapun hasil respon mahasiswa yang mengikuti pembekalan keterampilan berhitung dengan menggunakan model Mars dapat dilihat pada Grafik 1.

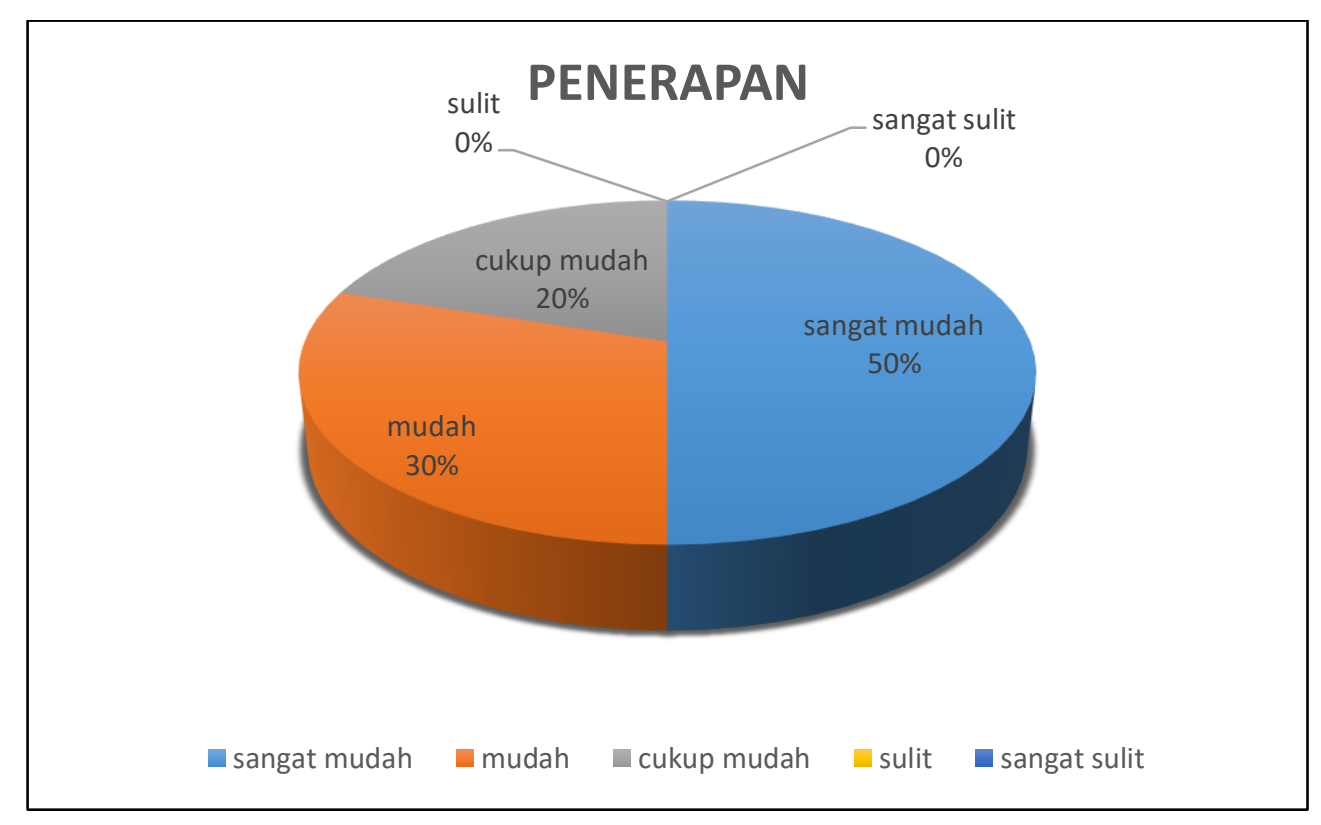

Grafik 1. Hasil Respon Mahasiswa Kegiatan Pelatihan 
Grafik 1 di atas dapat menunjukkan bahwa dari 30 mahasiswa yang mengikuti kegiatan PkM sebanyak 50\% memiliki pendapat bahwa model berhitung ini sangat mudah diterapkan, sedangkan $30 \%$ dari jumlah peserta menyatakan bahwa model berhitung mudah diterapkan, dan sisanya menyatakan cukup mudah diterapkan dalam perhitungan dengan operasi penjumlahan dan pengurangan sederhana. Hal ini sesuai dengan hasil penelitian yang dilaksanakan oleh Wulandari (2013) yang menyatakan berhitung dengan jarimatika merupakan cara berhitung yang dilakukan dengan cara yang mudah. Berhitung dengan jarimatika tidak memberatkan memori otak, karena alatnya senantiasa tersedia. Dengan demikian, saat ujian siswa tidak akan tertinggal karena waktunya tidak tersita. Berhitung dengan jarimatika adalah cara berhitung yang menyenangkan. Hal ini juga diperkuat oleh Bintoro (2015) yang menjelaskan bahwa teknik jarimatika ini mempermudah untuk belajar berhitung dan memperkenalkan matematika khususnya kepada anak-anak bahwa matematika (berhitung) itu menyenangkan.

Dari hasil ini dapat disimpulkan bahwa pembekalan keterampilan berhitung model berhitung Mars ini berdaya guna karena sebagian besar peserta menyatakan mudah diterapkan. Dengan demikian, kegiatan pembekalan keterampilan berhitung model mars (matematika dan aritmatika sederhana) ini sebagai acuan untuk pelaksanaan kegiatan serupa namun dengan perhitungan operasi perkalian dan pembagian.

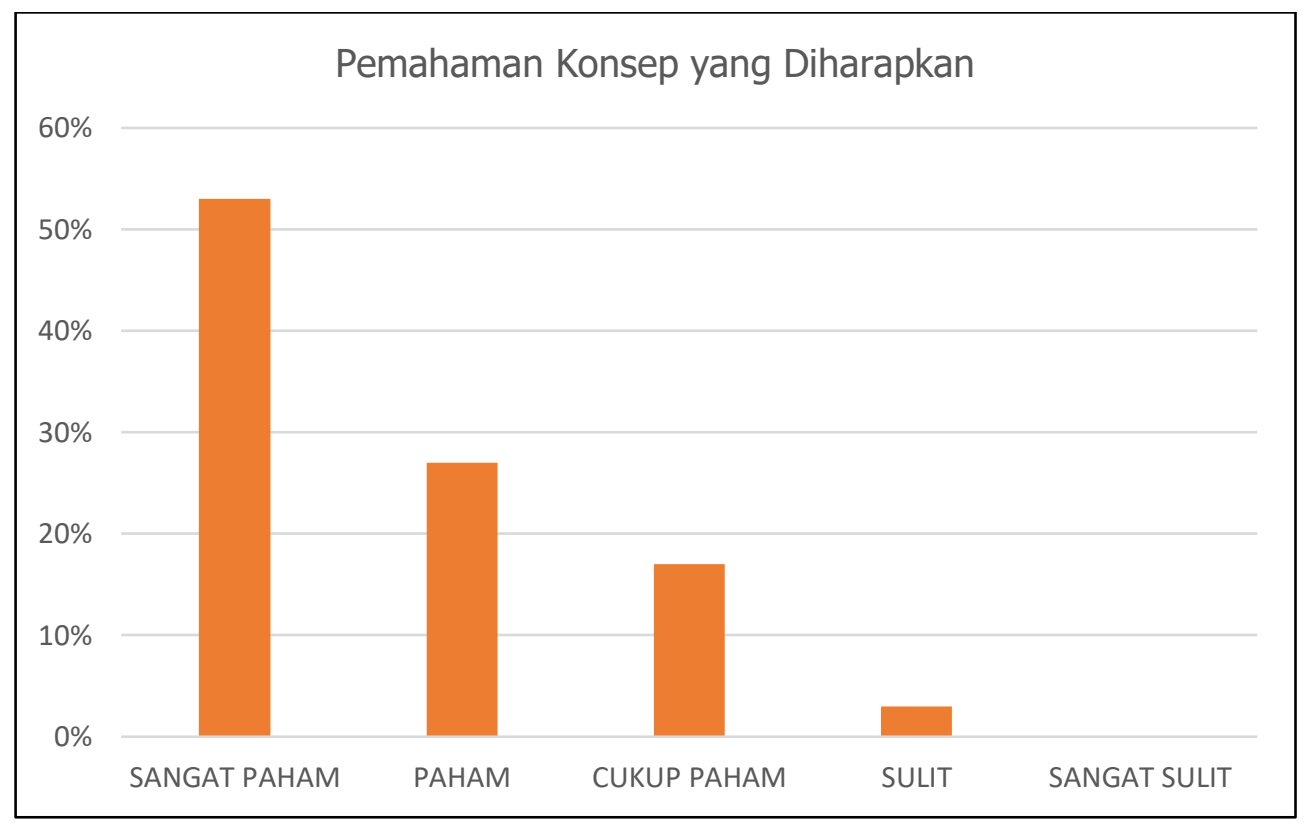

Grafik 2. Hasil Penerapan Kegiatan Pelatihan

Berdasarkan grafik 2 di atas, dapat dinyatakan bahwa sebagian besar peserta beranggapan siswa yang menerapkan jarimatika akan mempunyai pemahaman konsep yang lebih. Hal ini dapat dilihat dari prosentase tertinggi yaitu $53 \%$ dari jumlah peserta pelatihan menyatakan sangat paham terhadap konsep berhitung menggunakan jarimatika, 27\% dari jumlah peserta menyatakan paham terhadap konsep berhitung menggunakan jarimatika, $17 \%$ dari jumlah peserta menyatakan cukup 
paham terhadap konsep berhitung menggunakan jarimatika dan 3\% dari seluruh peserta menyatakan sulit terhadap konsep berhitung menggunakan jarimatika.

Hal ini sesuai dengan hasil penelitian yang dilakukan oleh Mulyono et al. (2012) yang menjelaskan bahwa teknik penggunaan jarimatika lebih menekankan pada pemahaman konsep matematika terlebih dahulu kemudian baru menggunakan jari-jari tangan. Menurut Kesumawati (2008) memperdalam pemahaman konsep merupakan landasan terpenting dalam rangka untuk meningkatkan kemampuan berpikir siswa dalam menyelesaikan permasalahan matematika ataupun permasalahan sehari-hari. Hal ini sejalan dengan pendapat Korn (2014) yang menyatakan bahwa pemahaman konseptual matematika juga dapat mendorong siswa untuk lebih mandiri dan percaya diri, sehingga siswa mampu memecahkan masalah dalam kehidupan sehari-hari dengan cara berbeda. Korn (2014) juga menjelaskan bahwa siswa yang memiliki pemahaman prosedural saja tidak cukup, melainkan perlu memiliki pemahaman konsep. Pemahaman konsep ini memberikan pendidikan yang lebih holistik. Hal ini juga dikuatkan oleh Stephanie Lem, Patrick Ongheno, Lieven Verschaffel \& Wim Van Dooren (2013) yang menyatakan bahwa pemahaman konsep mendasari proses penalaran.

Dari hasil ini dapat dinyatakan bahwa mahasiswa program studi pendidikan matematika paham dan dapat menerapkan keterampilan berhitung jarimatika. Kegiatan pelatihan ini juga sangat memungkinan untuk diterapkan karena kesulitan konsep jarimatima dapat dihadapi. Kedepan diharapkan keterampilan ini dapat digunakan untuk mendukung kemampuan mahasiswa ketika sudah terjun di dunia sekolah. Dengan adanya modal pelatihan bagi mahasiswa program studi pendidikan matematika dapat menjadikan pembelajaran yang mereka laksanakan akan menjadi pembelajaran yang bermakna. Berdasarkan hasil tracer Prodi Pendidikan Matematika tahun 2019 tingkat pengembangan diri mahasiswa lebih baik dibandingkan tahun-tahun sebelumnya. Dengan demikian kegiatan seperti ini mampu meningkatkan kualitas lulusan mahasiswa prodi Pendidikan Matematika menjadi lulusan yang profesional dengan dibelikan kemampuan akademik, kemampuan non-akademik, dan kemampuan keterampilan (skill).

\section{Kesimpulan}

Dengan adanya kegiatan pelatihan-pelatihan dari dosen untuk mahasiswa seperti Model Berhitung MARS (Matematika dan Aritmatika Sederhana), diharapkan mahasiswa mempunyai skill terkait dalam aritmetika sederhana sehingga mampu bersaing dalam dunia kerja (khususnya mendidik) khususnya pada operasi penjumlahan dan pengurangan sederhana. Kegiatan ini memberikan motivasi untuk Program Studi khusunya dalam meningkatkan mutu lulusan Program Studi Pendidikan Matematika.

Dengan demikian, selain diberikan bekal ilmu pengetahuan (ilmu matematika dan pendidikan), mahasiswa Prodi Pendidikan Matematika juga diberikan skill-skillseperti yang telah dilaksanakan dalam kegiatan pengabdian ini. Kegiatan ini dapat dilaksanakan kembali dengan menggunakan operasi yang lain yaitu perkalian dan pembangian sederhana. Dan kegiatan seperti ini mampu meningkatkan kualitas mahasiswa prodi Pendidikan Matematika Universitas Muhammadiyah Ponorogo menjadi lulusan yang profesional. 


\section{Ucapan Terima Kasih}

Terima kasih diucapkan kepada Universitas Muhammadiyah Ponorogo atas dukungannya terlaksananya Pengabdian kepada Masyarakat tahun anggaran 2018 dan pejabat serta kepada seluruh pihak yang terlibat dalam kegiatan pengabdian kepada masyarakat ini. Semoga kegiatan ini membawa kebaikan, manfaat dan keberkahan bagi semuanya khususnya para calon pendidik yang nantinya mampu bersaing dengan pendidik dari perguruan tinggi lainnya.

\section{Referensi}

Abdullah, M.K. (2012). Teknik Belajar Cepat Jarimatika. Jakarta: Sandro Jaya.

Anthony, G. and Walshaw, M. (2009). Characteristics of Effective Teaching ofMathematics: A View from the West. Journal of Mathematics Education. 2(2), 147-164.

Astuti, T. (2013). Metode Berhitung Lebih Cepat Jarimatika. Jakarta: Lingkar Media.

Bintoro, H. S. (2015). Pembelajaran matematika sekolah dasar menggunakan metode jarimatika pada materi perkalian. Prosiding Seminar Nasional Matematika dan Pendidikan Matematika UMS 2015, 72-84.

Darsono. (2000). Psikologi Pendidikan. Jakarta: Gasindo.

Kesumawati, N. (2008). Pemahaman Konsep Matematik dalam Pembelajaran Matematika. Semnas Matematika dan Pendidikan Matematika, 2, 231-234.

Khumaidah, N. (2007). Panduan Belajar Mental Aritmatika. Gresik: Master.

Korn, J. (2014). Teaching conceptual understanding of mathematics via a hands-on approach. (Thesis). Diakses di https://pdfs.semanticscholar.org.

Mulwa, E.C. (2015). Difficulties Encountered By Students In The Learning And Usage Of Mathematical Terminology: A Critical Literature Review. Journal of Education and Practice, 6 (13), 27-37.

Mulyono, H., Hadiyah, dan Suparno. (2012). Peningkatan Pemahaman Operasi Perkalian di Sekolah Dasar dengan Menggunakan Teknik Jarimatika. Didaktika Dwija Indria, 2(3), 1-5.

Primayanti, G., Suwu, E.S., dan Appulembang, O.D. (2018). Penerapan Metode Drill untuk Meningkatkan Kemampuan Komunikasi Matematis Siswa Kelas Viii Smp Lentera Way Pengubuan Pada Topik Persamaan Garis Lurus. Journal of Holistic Mathematics Education, 1(2),135-149.

Sitio, T. (2017). Penerapan Metode Jarimatika untuk Meningkatkan Hasil Belajar Matematika Siswa Kelas I SDN 003 Pagaran Tapah Darussalam Kabupaten Rokan Hulu. Jurnal Primary Program Studi Pendidikan Guru Sekolah Dasar Fakultas Keguruan dan IImu Pendidikan Universitas Riau, 6(1), 146-156.

Stephanie Lem, Patrick Ongheno, Lieven Verschaffel \& Wim Van Dooren. (2013). On the Misinterpretation of Histograms and Box Plots. Educational Psychology: An International Journal of Experimental Educational Psychology. 33(2), 155-174.

Syifa, F.M. \& Simatupang, N.D. (2015). Penggunaan sempoa dalam Pengembangan Kemampuan Berhitung Permulaan Anak. Jurnal Mahasiswa Teknologi Pendidikan, 4(2), 1-6.

Tambychik, T and Subahan, T.M.M. (2010). Students' Difficulties in Mathematics Problem-Solving: What do they Say?. International Conference on Mathematics Education Research 2010 (ICMER 2010), 142-151.

Wahyuni, N. (2016). Penggunaan Metode Drill Dalam Pembelajaran Matematika. Prosiding, 2(1), 399-406.

Wulandari, S.C. (2008). Jarimatika Perkalian dan Pembagian. Jakarta: PT Kawasan Pustaka.

Wulandari, S.C. (2013). Pembelajaran Berhitung Penjumlahan dengan Jarimatika . Jurnal Keilmuan dan Kependidikan MIPA, 8(1), 1-11. 